\title{
REGIONAL ASPECTS OF DEVELOPMENT AND FINANCING PECULIARITIES OF AGRICULTURE IN UKRAINE
}

\author{
Lesia DMYTRYSHYN' ${ }^{1}$, Bohdan BRYNZEI² \\ Vasyl Stefanyk Precarpathian National University, Ukraine
}

\begin{abstract}
The aim of this work is the study and generalization of conceptual foundations, problematic and peculiarities of functioning of agriculture in modern economic conditions, the conceptual foundations of state regulation at the regional level and features of their financial providing. Methodology. Theoretical and methodological basis of the research is the work of scientists on problems of financial providing of agriculture development. The authors used the combination of the following methods in the process of scientific investigation: generalization and scientific abstraction - to concretize the conceptual-categorical apparatus; monographic method - to present the views of scientists on this problem; comparative analysis - to detect the features of agriculture development and to compare instruments of its financial providing. Results. The functioning features of agricultural enterprises of the region in current economic conditions have been researched, highlighting fundamental principles: the rational use of resources; state regulation and state support; financial providing. The main purposes of state support of agriculture were determined in the article: increase in production of high quality products with the aim of solution of the food security problem; the increase of competitiveness of the agricultural sector to stimulate economic growth; the intensification of research work that will create competitive advantage for domestic producers in the long term perspective; development of rural areas; increase of rural employment and so on. Practical value. It was established that a significant number of unresolved financial problems of this economic sector requires the development and implementation of new, adequate to modern conditions, methodical approaches to financial and credit providing of industry, in particular the expansion of the market of banking services (project financing and forward loans, forfaiting, factoring); the widespread introduction of rural credit cooperation. The development of the national agricultural enterprises in new economic conditions is impossible without their financial support at the expense of investment resources. The optimal variant of financial policy of agricultural enterprises is the development of ways of attracting and using of financial resources for the future to achieve strategic and tactical goals of the company. In this case income must be generated and used in accordance with the scale of production and real tasks, taking into account the dependence of receipts from the influence of external and internal factors; expenses should consider their economic validity and the minimization, confirmed by the respective financial calculations, and differentiation by their degree of importance and areas of use. The main problem of financial providing of agricultural enterprises of the region at the present stage is the absence of a mechanism of integrated use of traditional and non-traditional sources of financial resources for the national managing conditions. Originality. On the basis of this study the authors proposed conceptual framework for financial support of agricultural enterprises that constitute the basis of scientific research to establish an effective models of financing of agricultural producers.
\end{abstract}

Key words: agriculture, development, financial resources, state support, region.

JEL Classification: Q1, O13, G18, H1, H7

\section{Introduction}

Agriculture as one of the most promising sectors of Ukrainian economy in modern conditions requires the formation of measures to overcome the decline in production, strengthening of a financial state of agricultural producers, the use of existing reserves, the transition of agricultural production to the innovative type of development. Under these conditions the role of the state in supporting of the agricultural sector is the most significant for the formation of effective

\footnotetext{
Corresponding author:

${ }^{1}$ Department of Economic Cybernetics, Vasyl Stefanyk Precarpathian National University.

E-mail: dmytryshyn_1@hotmail.com

${ }^{2}$ Department of Economic Cybernetics, Vasyl Stefanyk Precarpathian National University.

E-mail: bogdan.bc.2201@mail.ru
} 
organizational and economic mechanism of its functioning.

Theoretical questions on the issues of state regulation and features of financial providing of agricultural producers were studied by the following national scientists: M. Ya. Demianenko, O. Ye. Hudz, P.A.Stetsyuk, V.P. Synchak, A. V. Chupis, V.A. Borysova, S. M. Kvasha, Yu. O. Lupenko, O. O. Nepochatenko, N. S. Prokopenko etc. However, despite the great diversity of scientific issues and the depth of their investigation in modern economic science, insufficient attention is paid to methods and tools for additional access to financial resources by agricultural enterprises.

The aim of the article is the study and generalization of the conceptual foundations, problematic and peculiarities of functioning of the rural sector in the current economic environment, the conceptual foundations of state regulation at the regional level and peculiarities of their financial providing.

\section{State financing of agriculture}

In the conditions of transformation of Ukrainian economy a balanced combination of state regulation of agrarian sector with the mechanisms of the free market is extremely important. In this case we should carefully apply the measures of direct intervention in the market, which has proved their low efficiency in most developed countries, and we should give preference to measures aimed at improving the efficiency and competitiveness of agricultural production (Ivanko, 2006).

To promote agricultural development government must support productivity growth, improve food security at household level and stabilize the market. Innovative development of agricultural production and processing, the creation of a modern national system of industry informatization as close as possible to the needs of the agrarian market subjects, ensuring of constructive interaction between the state and agricultural business, control over observance of requirements of ecological safety of agricultural production and food quality must become the main directions of state regulation and support. Along with this, in the modern socioeconomic conditions, the effectiveness of state economic regulation of the agro-industrial complex is directly based on the rational combination of measures at the central and regional levels, and it requires the development of fundamentally new methodology of the state regional agricultural policy.

During determining the development priorities, goals and objectives of regional policy the main attention should be paid not so much to the choice between the principles of fairness and efficiency, but to the search of their optimum ratio and also the proper distribution of functions between the centre and the regions. The economic basis for a modern agricultural policy should be not only quantitative increase of agricultural production and profitability of agricultural enterprises, but also integrated satisfaction of the growing needs of region subjects in terms of better living conditions, environmental safety and social development.

Taking into account the specificity of regional agrarian policy in Ukraine, regulatory support, administrating, financial, economic and social regulation should be its main methods at the present stage, which will create a temporary favorable conditions mainly for new, strategically important for regional agriculture enterprises, providing their restructuring. In addition, modern regional agricultural policy should take into account structural, social and institutional factors that will ensure not only the growth of agricultural production, but also complex economic, environmental and social development of the region.

Riabokon (Riabokon, 2001) indicated that in the present circumstances of agricultural production in the region we need active using of functional management relations. The Ministry of agrarian policy of Ukraine should be a key unit of the management institutions which unites along with the state also professional, cooperative and corporate associations of agricultural producers, inter-professional associations of operators of food markets, which have a part of the government functions and are created on democratic principles. It should be noted that in modern economic literature, bipolarization is considered the most effective way of formation and using of the operators of the grocery market, which is achieved by the methods of vertical production and marketing integration, where the operator on the supply side acts as one integrated manufacturer and on the demand side - as the end consumer. In this case, the competition is moved to the area of assessments of the end user, which determines the matching measure of quality and prices of the offered products to his requirements.

The authors (Lupenko, Mesel-Veseliak, 2012) noted that in order to use the potential of agriculture more fully a profitable environment should be created primarily for the functioning of different organizational and legal forms of management in agrarian sector on an equal economic basis; for harmonization of interests of owners, employees and rural communities; for the formation of a competitive production structures on internal and external markets; for provision of profitability of agricultural enterprises at the level of 15 percent necessary norm to ensure the expanded reproduction of the production.

This can be achieved through the continuation of reforms in the country's economy and its agricultural sector towards the optimal combination of industrial and agricultural production, the subordination of their activities to the needs of internal and external markets of agricultural products and foodstuffs, socio-economic development of rural areas, the transition from sectoral to territorial-self-governing management system of 
integrated development of agricultural production and rural areas, the formation of an effective scientifictechnological, budgetary, tax, financial, credit and pricing policy.

In this case, it is worth noting that according to the report "Economic results of agricultural production in 2014", the financial result from operating activities of agricultural enterprises (except small) in 2014 amounted UAH 34.5 billion profit against UAH 12.3 billion in 2013; the income from production of agricultural products and services in crop and livestock production received $81.5 \%$ of enterprises, profit amounted UAH 5,8 million in average for one enterprise. In 2013 this indicator was respectively $64.3 \%$ and UAH 3.2 million. Thus, the profitability of crop production and production of agricultural products and services decreased in 2013 against 2012 in almost two times (The official website...).

State support of national agricultural producers, as it is known, can be arranged not only through direct budget payments, it may be arranged in the form of indirect measures (purchase and commodity interventions with grain, purchases of agricultural products and foodstuffs for state needs etc.). It is also impossible to agree with the conclusions: "government support is a combination of various instruments and tools of financing", "state support is a payment from the state budget". Support is supplemented by such effective measures of organizational-economic character of the state as the organization of leasing operations, debt re-structuring of agricultural organizations, cancellation of penalty from enterprises, organization of the system of credit cooperation, stimulating of the creation of agricultural consumer, trade and purchasing, processing and service cooperatives, the introduction of the unified agricultural tax, etc.

So, according to most scientists, the main objectives of the state support of agriculture are increasing of production volumes of high-quality products with the aim of solution of food security problem; the competitiveness of agrarian sector of economy for stimulation of economic growth; intensification of research work that will create competitive advantage for national producers in long term perspective; the development of rural areas; increasing of employment of the rural population (Hudz, 2007; Luzan, 2008; Oliynyk, 2009; Vasylchak, 2009).

\section{Credit-investment and insurance instruments of financing}

Development of the national agrarian enterprises in new economic conditions is not possible without their financial support at the expense of investment resources. The crisis in the global and national economies led to the reduction of investment pro-grams of national and foreign investors in the agricultural sector of
Ukraine. The modern character of Ukrainian economy determines the need for national agricultural enterprises in the investment support, which will promote not only the maintenance but also the development of industry (Liashenko, 2014).

The intention of agricultural enterprises to development, innovation, effective activity in conditions of constant shortage of financial resources causes the constant need for borrowing. The use of borrowed capital provides the opportunity to expand the scope of investment activities of enterprises, to provide more effective use of private capital, to accelerate the formation of various trust funds and eventually increase the market value of the enterprise.

Credit resources play a crucial role in the development of agriculture. This is due to the seasonal gap between the investments and continuity of the reproduction processes. Significant requirement in working capital with insufficiency of own funds transforms loan into significant source of formation of financial resources and necessitates a search of ways of credit support. However, loan obtaining by enterprises of the agrarian sector remains problematic. This is largely due to (Oliynyk, 2013) a decrease in state support for villages; inaccessibility of credit resources for rural entities because of high interest rates; disregard of seasonal work during crediting. Further development of market relations has caused the dependence of the agriculture functioning from the financial-credit system.

We should emphasize that regardless of the amount of loans granted to rural agriculture, only this region achieved the highest growth of gross output compared with other sectors of the economy that largely reflects the effective use of financial resources. The trend of crediting is due to both subjective and objective factors. It is known that one of the conditions for credit receiving is the creditworthiness of the borrower, that is a guarantee of repayment. In conditions of low profitability and often unprofitableness, low liquidity of the assets, the agricultural enterprises are often not creditworthy. The result is a vicious circle: the lack of financial re-sources is the reason for the low efficiency of agricultural production, which in its turn makes it impossible to obtain credit. In these circumstances, we need a development and implementation of new, adequate to modern conditions, methodical approaches to financial and credit providing.

The main tasks for improving of crediting of agricultural enterprises are: the expansion of the market of banking services (introduction of nontraditional ways of crediting by Ukrainian banks, which are widespread in Europe, - project financing, forward crediting, forfaiting, factoring); an enlargement of possibilities and the promotion of alternative financial institutions; the development and application of all possible sources for capital attraction during crediting of rural agriculture (rational use of budgetary 
funds, increase of assignations from the state for crediting, attraction of foreign credits, the creation of mechanisms of public, banking or mixed crediting); resolution of property and land issues; the solution of the problems of old debts.

According to (Oliynyk, 2013), the key foundation of the system of financial providing of agricultural enterprises are financial resources that can be generated from own, borrowed and non-repayable sources. And their main problem is a rational use of the use, the accumulation and formation of financial resources in the process of economic activities that form the basis of the effective financial policy of the enterprise. The optimal variant of financial policy of agricultural enterprises is the development of ways of attracting and using of financial resources for the future to achieve strategic and tactical goals of the company. In this case income must be generated and used in accordance with the scale of production and actual tasks, taking into account the dependence of financial revenues from the influence of external and internal factors; expenses should analyze their economic validity and the minimization, confirmed by the relevant financial calculations, and differentiation by a degree of their importance and directions of using.

The main problem of financial providing of agricultural enterprises of the region at the present stage is the absence of a mechanism of integrated use of traditional and non-traditional sources of financial resources for the national managing conditions. Another direction of improvement of financial provision of agricultural enterprises is the conclusion of forward contracts, which will give the opportunity to replenish their financial resources on an interest free basis. Advantages of forward contracts for agricultural enterprises are the following: the flow of financial resources at key stages of production, high purchase prices for the products and their guaranteed sales, way of insuring of price risks.

So, at the present stage of development of the agrarian economy there is a necessity of organization

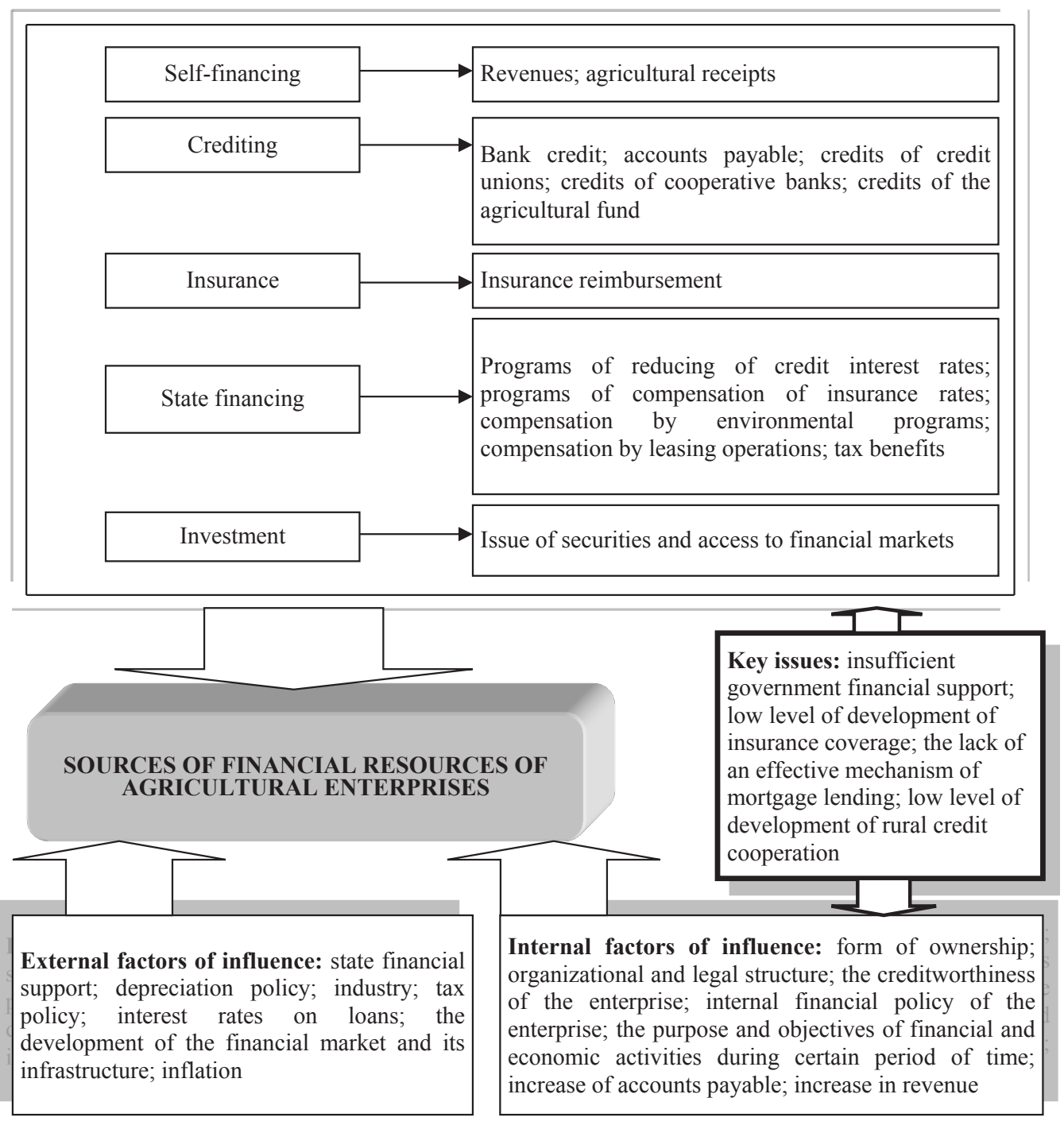

Fig. 1. Conceptual framework of financial support of agriculture 
of widely available credit network for rural entities by means of combining and enhancing of the existing rural financial resources. In Ukraine today, credit cooperatives are represented by credit unions, which unfortunately have not the possibility of legal crediting of subjects of entrepreneurial activity. Consequently, it is advisably to develop the system of rural credit cooperation based on the experience of foreign countries.

Rural credit cooperatives are self-regulated organizations, controlled by their members; their rights and obligations differ in the following ways: making deposits, obtaining loans, participating in the work of the cooperative (Oliynyk, 2013). According to the data (The official website...), 01.01.2015 in Ukraine there were 613 agricultural service cooperatives, among them 147 - cooperatives of cultivation and harvesting, 179 - dairy, 34 - grain, 163 - processing and marketing of meat, 66 - fruits and vegetables, 171 - cooperatives of another specialization. This fact indicates about high potential of development in this area, because the need for financial mechanism is not actually implemented through the national banking system.

The scientist (Hudz, 2007) proposes to group financial resources by the fol-lowing classification criteria, taking into account new economic conditions of management of agricultural enterprises: variation level of income, planning methods, forms of usage, risks of invested financial resources, form of exposure, level of exposure, form of establishment, membership in the economic process, method of accumulation, the purpose, the stage of movement. The mechanism of ensuring of the financial resources for enterprises is shown as a set of interrelated economic relations, which appears during search, formation, accumulation, using and ensuring of financial resources in accordance with objectives. The defining characteristic of this mechanism is the movement of financial resources.

\section{Conceptualization of the study}

On the basis of this study the following conceptual framework of financial providing of agricultural enterprises has been proposed (Fig. 1).

\section{Conclusions}

Consequently, the development of agricultural production in the regional aspect should be based on the effective mechanism of state support, as improving the effi-ciency of agricultural production is hampered by the lack of financial resources in the industry. This requires the improvement of crediting of agricultural enterprises, that is the expansion of the market of banking services; empowerment and promotion of the development of alternative financial institutions; development and application of all possible sources to raise capital during agriculture crediting; solution of property and land issues; the solution of the problems of old debts, as well as the implementation of appropriate investment programs.

One of the possible solutions of improvement of the financial state of agricultural enterprises in the region can be the creation of appropriate credit cooperatives, which will contribute to improvement of the state of agriculture in the region; increase of employment and income of the rural population; development of rural areas; middle-class formation and the solution of social problems of rural communities; expanding access to credits for small businesses in rural areas and other categories of borrowers. Taking into account the importance of creation in Ukraine of the cooperative credit system, especially for financial and credit services to rural areas, the government should support this process.

Researched and analyzed conceptual features of the functioning and financial security of agriculture in the current economic conditions will form the basis of future research on the formation of an effective model of financing of agricultural producers.

\section{References}

Demianenko, M.Ya., Ivanyna, F.V. (2008). State support as an ensuring factor of competitive agricultural production. Ekonomika APK (Economics of agro-industrial complex), 9, pp. 3-10.

Hudz, O.Ye. (2007). Financial resources ensuring of the agricultural enterprises: dis. abstract. ... doctor of econ. sciences: spec. 08.00.03 "Economy and management of enterprises (economics of agriculture and agro-industrial complex)". National scientific center "Institute of Agrarian Economics" UAAS, 39 p.

Ivanko, A.V. (2006). Regulation of agricultural production of the region: dis. abstract ... cand. of econ. sciences: spec. 08.07.02 "Economics of agriculture and agro-industrial complex". National Agricultural University, $31 \mathrm{p}$.

Liashenko, V.I. (2014). The first phase of modernization of economy of Ukraine: experience and problems. Zaporizhzhia: KPU, 798 p.

Lupenko, Yu.O., Mesel-Veseliak, V.Ya. (2012). Strategic directions of development of agriculture of Ukraine for the period until 2020. K.: NNTs «IAE», pp. 7-11.

Luzan, Yu.Ya. (2008). Development of state support of agrarian sector of Ukraine in the conditions of WTO membership. Oblik i finansy APK (Accounting and finance of agro-industrial complex), 3, pp. 6. 
Oliynyk, K.A. (2013). Financial support of small agricultural enterprises: dis. abstract ... cand. of econ. sciences: spec. 08.00.04 "Economy and management of enterprises (by economic activities)". Mykolaiv Nat. Agrarian university, $23 \mathrm{p}$.

Oliynyk, T.I. (2009). State support of agrarian sector of economy of Ukraine. Ekonomika APK (Economics of agro-industrial complex), 7, pp. 80-85.

Riabokon, V. P. (2001). Economic and social problems of development of agriculture of Ukraine in modern conditions: dis. abstract. ... doctor of econ. sciences: spec. 08.07.02 "Economics of agriculture and agro-industrial complex". Institute of Agrarian Economics of UAAS, $47 \mathrm{p}$.

The official website of the State statistics service of Ukraine. Retrieved from: http://www.ukrstat.org.ua.

Vasylchak, S.V., Datsiuk-Tomtchuk, M.B. (2009). Topical issues of state support of competitiveness of agricultural production. Visnyk SNAU (Bulletin of SNAU), 4, pp. 95-98.

\section{Леся ДМИТРИШИН, Богдан БРИНЗЕЙ}

\section{РЕГИОНАЛЬНЫЕ АСПЕКТЫ РАЗВИТИЯ И СПЕЦИФИКА ФИНАНСИРОВАНИЯ СЕЛЬСКОГО ХОЗЯЙСТВА УКРАИНЫ}

Аннотация. Целью работы является исследование и обобщение концептуальных основ, проблематики и особенностей функционирования сельского хозяйства в современных экономических условиях, концептуальных основ государственного регулирования на региональном уровне и особенностей их финансового обеспечения. Методика. Теоретическую и методологическую основы исследования составляют труды ученых по проблемам финансового обеспечения в сфере развития сельского хозяйства. В процессе научного исследования использовалась совокупность следующих методов: обобщение и научной абстракции - с целью конкретизации понятийно-категориального аппарата; монографический при освещении взглядов ученых на исследуемые проблемы; сравнительного анализа - при выявлении особенностей развития сельского хозяйства и сопоставлении инструментов его финансового обеспечения. Результаты. Исследованы особенности функционирования сельскохозяйственных предприятий региона в современных экономических условиях с выделением принципиальных положений: рационального использования ресурсов; государственного регулирования и государственной поддержки; финансового обеспечения. Установлено, что основными целями государственной поддержки сельского хозяйства являются увеличение объемов производства продукции высокого качества с целью решения проблемы продовольственной безопасности; повышение конкурентоспособности аграрного сектора экономики, что будет стимулировать рост экономики; активизация научно-исследовательской работы, что создаст конкурентное преимущество национальных товаропроизводителей в долгосрочной перспективе; развитие сельских территорий; повышение занятости сельского населения и тому подобное. Практическое значение. Установлено, что значительное количество нерешенных финансовых проблем данной сферы хозяйствования вызывает необходимость разработки и реализации новых, адекватных современным условиям методических подходов к финансово-кредитному обеспечению отрасли, в частности расширение рынка банковских услуг (проектное финансирование, форвардное кредитование, форфейтирование, факторинговые операции); широкое внедрение сельской кредитной кооперации и тому подобное. Также развитие национальных аграрных предприятий в новых экономических условиях невозможно без их финансовой поддержки за счет инвестиционных ресурсов. При этом оптимальный вариант финансовой политики сельскохозяйственных предприятий заключается в разработке направлений привлечения и использования финансовых ресурсов на перспективу с целью достижения стратегических и тактических целей предприятия, при которых доходы должны формироваться и использоватьсяв соответствии смасштабамипроизводства и реальнопоставленных задач, с учетом зависимости финансовых поступлений от влияния внешних и внутренних факторов; расходы должны учитывать их экономическую обоснованность и минимизацию, подтвержденную соответствующими финансовыми расчетами, и дифференциацию по степени их важности и направлениям использования. Основной проблемой финансового обеспечения сельскохозяйственных предприятий региона на современном этапе является отсутствие механизма комплексного использования как традиционных, так и нетрадиционных для отечественных условий хозяйствования источников финансовых ресурсов. Значение/оригинальность. На основе проведенного исследования предложены концептуальные основы финансового обеспечения сельскохозяйственныхпредприятий, положенные в основу научных исследований по формированию эффективной модели финансирования сельскохозяйственных производителей. 